TONY SANDERS

\title{
DESSERTS WITH SOME OPINIONS ABOUT FRUIT AND SO BE IT
}

Whatever happened to those coyotes when the dregs, The morning glories of last night's aftermath, Met for pancakes, or else cupcakes when she Decided not to back into the headwind of life Sidewise, opinionated as she was, and cycled, Giggling at the same time as forewarned About flunk-outs privy to the inside dope Of sadness sending signals to mutts, beholden To their owners of not their moms, a long Way from the eloquence of beef jerky alone, In silence, stylish, in the way some approve, Though they don't vote, except forever, Because once in a while sadness, anger, And forgiveness all have their take-out together, Forever who she is, gambler in hock, or slightly, Federally for that holiday in arrears. So what? As the fandango says, go on, let's Just say I'm no longer improvisational beyond Allure, the untoward hound still walks toward The meat, cold meat adorned by raw veggies You don't like, especially, and even more, When you like something you don't even hear Floating, or should the Pope say sifting, Albeit, I speak Italian, hey-hey, Nobody speaks Italian, except on cue, With misery in the company of errant Rainbows, your goodness shows beyond, And far, far beyond in its mineral wilderness, Love.

Love and kisses, 